\title{
The Effect of Board Characteristics on Internet Financial Reporting Quality: Evidence from Malaysia
}

\author{
Mathew Kevin Bosi ${ }^{1}$, Mohd Noor Azli Ali Khan ${ }^{2}$, Nelson Lajuni ${ }^{3}$, Ag Kaifah Riyard ${ }^{4}$ \\ 1,3,4 Faculty of Business, Economics and Accountancy, Universiti Malaysia Sabah, 88400 Kota Kinabalu, Sabah \\ Malaysia, ${ }^{1}$ E-mail: mkevin@ums.edu.my (Corresponding author) \\ ${ }^{2}$ Azman Hashim International Business School, Universiti Teknologi Malaysia, 81310 Johor Bahru, Johor, Malaysia
}

\begin{abstract}
The emergence of digital technology has spurred utilization of internet financial reporting (IFR). However, without the initiative from a corporate board to address issues such as lacking vigorous regulations that prescribing best practices of online business reporting, IFR quality may not be elevated accordingly. The main objective of this study is to determine the extent of qualitative characteristics of IFR across Malaysian listed companies by examining the relationship between board characteristics and IFR quality (IFRQ), moderated by Effectiveness of Internal Audit Function (EIAF). Qualitative approach via non-probability purposive sampling was used to select the companies from 11 relevant industries in Malaysia, to which 160 companies were selected to examine these correlations. The data were analysed using Partial Least Squares Structural Equation Modelling (PLS-SEM) via WarpPLS version 7.0. The results prove that board size, independence of directors, and female directors significantly improve IFRQ. The EIAF appears to moderate only independent directors. This could be due to substitute effect between board quality and internal audit quality. This study provides a better understanding of the role of board characteristics towards improving IFRQ and enriching the literature on IFR measurement mechanism.
\end{abstract}

Key words Internet Financial Reporting, Board Characteristics, Corporate Governance, Qualitative Characteristics

$\begin{array}{rrr}\text { Received: } & \text { O6 Jul } 2020 & \text { (C) The Authors } 2020 \\ \text { Revised: } & 20 \text { Aug } 2020 & \text { Published by Human Resource Management Academic Research Society (www.hrmars.com) } \\ \text { Accepted: } & 23 \text { Sep } 2020 & \begin{array}{l}\text { This article is published under the Creative Commons Attribution (CC BY 4.0) license. Anyone may } \\ \text { reproduce, distribute, translate and create derivative works of this article (for both commercial and } \\ \text { non-commercial purposes), subject to full attribution to the original publication and authors. The full } \\ \text { terms of this license may be seen at: http://creativecommons.org/licences/by/4.0/legalcode }\end{array}\end{array}$

\section{Introduction}

Internet Financial Reporting (IFR) has become the focal point of discussions among practitioners and researchers as the global economy is undergoing a rapid digital transformation by structuring new concept in the manner how businesses are operated and interact with their stakeholders (Cassar et al., 2019). In a similar vein, Efimova \& Rozhnova (2018) encourage to leverage the full benefits of digital technology use to improve the usefulness of information disseminated through online business reporting such as IFR as one of the means to move forward during technological climate change. The body of literature shows how IFR has become essential to stakeholders more so to the investors in providing them with enormous benefits which the traditional printed-based financial reporting unable to offer. Accordingly, IFR encourages firms to disclose both financial and non-financial information which is vital for economic investment decision making (Xiao et al., 2004). It also enables for dissemination of voluminous disclosure on corporate performance and activities on corporate websites, thereby reduces information asymmetry between companies and their shareholders (Ojah \& Mokoaleli, 2012; Gajewski \& Li, 2015). Another important aspect 
that significantly distinguishes between IFR and printed-based reporting is that the former allows for dissemination of information in real-time manner, thus, users of financial reports especially investors can obtain the most recent information for their economic decision-making (Hanafi et al., 2009; Nel, 2016; Ariff, Bin-Ghanem \& Hashim, 2018). Nevertheless, given the fact that IFR practices are still predominantly unregulated and voluntary, including lack of specific accounting standards to address issues on IFR disclosure, it is anticipated that this phenomenon can have adverse impact on the quality of information brought via IFR (Amin \& Mohamed, 2016; Efimova \& Rozhnova, 2018). On another note, prior research shows that vast majority of studies have been using variety of indexes measurements as proxies to evaluate IFR quality (Kelton \& Yang, 2008), which refers to IFRQ as being used in this current study. The researchers argue that the indexes measuring mechanisms tend to be focusing more on items that are disclosed in annual reports rather on the quality of information.

Further, according to Hanafi et al. (2009), index-based mechanism placed more emphasis on financial information rather than non-financial information. The researchers also added that although these index mechanisms placed more emphasis on financial data, the assessed attributes are not accord with provisions recommended by International Accounting Standards (IAS). Prior literature also proves that there is a paucity of studies conducted to assess the qualitative characteristics of IFR. Hence, this study attempts to adopt a measurement instrument which comprises of qualitative attributes developed from studies by past researchers (Pirchegger \& Wagenhofer, 1999; Beest et al., 2009, Braam \& Beest, 2013; Al-Dmour et al., 2017) to determine the level of quality on the usefulness of information across Malaysian listed companies. This research also aims to examine the relationship between board characteristics and IFRQ from Malaysian perspectives. Although several past studies have investigated the correlation between these two variables, the results appear to have lack of consensus. Hence, this study employs effectiveness of internal audit function (EIAF) to moderate the correlation between boards' characteristics and IFRQ. The research is also in line with the suggestions made by several researchers, highlighting the need to constantly examine the relationship between IFR disclosure quality and board characteristics, given that business landscape and the practices of corporate governance which are constantly evolving (Kelton \& Yang, 2008; Sandhu \& Singh, 2019). Further, according to Mokhtar (2017), research on the relationship between board characteristics and IFR disclosure is still considered scant particularly in the emerging markets like Malaysia.

\section{Literature review}

Literature review shows that vast majority of studies have been using quantitative method such as index measuring instruments to assess IFR quality (Pirchegger \& Wagenhofer, 1999; Amilia, 2015; Alebrahem, 2018). In contrast, only several researches had been conducted to meausre the qualitative characteristics of IFR (Dyezkowska, 2014; Amin \& Mohamed, 2016). This can be explained by the complexity in operationalizing the qualitative nature in the form financial reports (Beest et al., 2009). On another note, there is only few studies that engages the use qualitative method, using interview mechanism to gauge IFR quality (Arafa, 2012; Ahmed et al., 2018). It is claimed that qualitative approach may provide a more in-depth insights in explaining IFR dimensions, however, it is argued that the approach can be easily influenced by the force of biasness in a way that the respondents may not provide truthful and consistent responses as they may be influenced by the event such as management pressure (Ahmed et al., 2018).

\subsection{Issues with IFR quality}

The underlying theory used in this study to describe IFR quality is signaling theory. According to Morris (1987), signaling theory propounds that high-quality companies usually apply appropriate accounting methods and principles to generate high-quality financial reports, while poor quality companies will do the opposite to cover the poor quality of their financial reports. Currently, it is apparent that IFR practices are still largely unregulated (Sia et al., 2018). It is also marred by lack of mandatory or specific accounting standards addressing on the matters of IFR disclosure particularly the information that is released on corporate websites (Keliwon et al., 2018). This can cause massive impact on the quality of usefulness of information provided via IFR (Kelton \& Yang, 2008; Efimova \& Rozhnova, 2018). For example, the unfettered regulations and guidelines have given a management the opportunity to exercise 
opportunistic behavior to manipulating the IFR disclosure by way of deciding on the extent, type and the timing of releasing the information on corporate website (Sherman \& Young, 2016; Keliwon et al., 2017). This has caused a variation of IFR voluntary disclosure (i.e. mainly non-financial information) and lack of comparability across companies globally (Efimova \& Rozhnova, 2018). Another growing threat is the security risk in a sense that the IFR information can be penetrated by unauthorized personnel or outsiders who tries to access and obtain confidential information or ruin data for personal gain. This can be easily done in a condition where companies having lack of security systems on their corporate websites (Sia et al., 2018). This type of digital business attack has already occurred in several major countries like Russia (Efimova \& Rozhnova, 2018), United States, Canada and China (Cumming et al., 2017). Given the emergence of technology and the phenomenon by which IFR disclosure and practices are marred by lack of rigorous regulations and standards addressing the issue of IFR, this becomes barriers in providing usefulness of information to investors and other key stakeholders. Further, since these problems have the propensity which can cause negative effect on IFRQ, this warrants for assessment on IFRQ which focuses on its qualitative characteristics. This is also in response to the suggestions made in past literature, citing that the research pertaining to assessing qualitative characteristics of IFR is still considered scarce (Khan, 2007; Kelton \& Yang, 2008; Dolinsek \& Lutar-Skerbinjek, 2018; Effimova \& Rozhnova, 2018). Hence, this study aims to adopt suitable mechanism developed from prior literature that is capable to assess IFR quality, placing more emphasis on the qualitative characteristics of IFR in order to determine the level of usefulness of information.

\subsection{Issues with IFR Measurements}

Even though indexes measurements have contributed to many aspects of IFR dimensions, there are still some drawbacks that need to be addressed in order to improve the mechanism used to assess IFR. For example, Kelton \& Yang (2008) argue that indexes mechanisms emphasize items included in annual report, suggesting that quality on usefulness of information are being discounted. Moreover, the study by Mbobo \& Ekpo (2016) is also in support of the notion, debating that indexes measurements are inadequate to capture the specific qualitative attributes on the ground that they use indirect proxies (i.e. financial ratios, timeliness, checklist) to gauge the level of IFR quality. Meanwhile, Hanafi et al. (2009) connote that the orientation of index-based measurements is more leaning towards financial rather than non-financial information, which is also not in line with provisions recommended by International Accounting Standards (IAS).

\subsection{Rationale for Adopting Measuring Mechanism to Assess Qualitative Characteristics of IFR}

This study is conducted as a response to the suggestions provided in the literature, which justifies the need to assess qualitative characteristics of IFR in order to better understand the level of usefulness of information (Kelton \& Yang, 2008; Alali \& Romero, 2012; Almilia, 2015; Dolinsek \& Lutar-Skerbinjek, 2018). Another rationale for assessing the qualitative nature of IFR is that it enables for direct assessment on the attributes of IFR, which is deemed to provide more reliable results (Ahmed et al., 2013; Mbobo and Ekpo, 2016). The dimensions which are assessed in this research encompass financial and non-financial information derived from annual reports including technology features from corporate websites. This is to improve the comprehensiveness of assessment on IFR quality. Additionally, it is also important to consider the measured items for IFR that is linked to specific attributes recognized by International Accounting Standards (IAS) which is converged via Malaysian Accounting Standards Board (2018). Table 1 illustrates the measured attributes used in this study. 
Table 1. The Quality of IFR Measures

\begin{tabular}{|c|l|c|l|}
\hline No. & Qualitative Characteristics & Measured Items & \multicolumn{1}{c|}{ References } \\
\hline 1. & Relevance & 7 & $\begin{array}{l}\text { Beest et al. (2009); FASB (2013); Al-Dmour et al. (2017); MASB } \\
\text { (2018) }\end{array}$ \\
\hline 2. & Faithful representation & 3 & Beest et al. (2009); Al-Dmour et al. (2017), MASB (2018) \\
\hline 3. & Verifiability & 1 & Jonas \& Blanchet (2000); Beest et al. (2009); MASB (2018) \\
\hline 4. & Understandability & 7 & $\begin{array}{l}\text { Beest et al. (2009); Hassan \& Martson (2010); AL-Dmour et al. } \\
\text { (2017); MASB (2018) }\end{array}$ \\
\hline 5. & Comparability & 6 & Beest et al. (2009); IASB (2010); MASB (2018) \\
\hline 6. & Timeliness & 10 & $\begin{array}{l}\text { Pircheggar \& Wagenhofer (1999); Davey \& Homkajohn (2004); } \\
\text { Nel (2016) }\end{array}$ \\
\hline & & Total=34 attributes & \\
\hline
\end{tabular}

\subsection{Board characteristics}

Agency theory has been considered as the underpinning theory in this study, which rationalizing reason for management (e.g. companies' board) to protect the interest of investors by providing them with sufficient and reliable information for their economic judgment (Kelton \& Yang, 2008; Yap et al., 2011). The theory was also applied by Ojah \& Mokoaleli-Mokoteli (2012) in their studies to explain the increased voluntary disclosure, thereby, not only reduces information asymmetry but also cost of capital. However, the theory also postulates that the relationship between management and shareholders could yield two effects, either complementary or substitute (Ho \& Wong, 2001; Sandhu \& Singh, 2019).

While complementary effect often reflect effectiveness of board leads to improved quality of financial disclosure, substitute effect on the other hand, indicates that even with the presence of board, it does not necessarily lead to improvement on quality of IFR as it can be substituted with other internal corporate governance component. Companies across the globe have been scrutinizing their corporate governance practices following the occurrences of the corporate collapse of Enron and WorldCom due to financial scandals, followed by financial crisis in 2008 (Mousa et al., 2012). The downfall of giant corporations and the aftermath of financial crisis 2008 have prompted Malaysian Government to acknowledge the need to embrace the best practices of good corporate (Mousa et al., 2012). This is because of the factor that the corporate collapse was linked to poor practices of corporate governance by the management (Dharmadasa et al., 2014). The study by Sandhu \& Singh (2019) indicates that corporate governance mechanism particularly board characteristics have the propensity to influence the characteristics and level of IFR disclosures. This is also illustrated in the works of Alebrahem (2018) and Sia et al. (2018), revealing that the management via good corporate governance encourages the use of website to disclose additional voluntary disclosure for their stakeholders. Further, Mokhtar (2017) reveals that there is still paucity of research examining the association between board characteristics and IFR practices. Also, in light of the initiation of Malaysian Code of Corporate Governance 2017, it is important to note that much of attention has been given to board characteristics (i.e. board composition, female directors on board, directors participation in audit committee, and risk management committee) in order to take current practices of corporate governance to a new height.

\subsection{Board Size and IFRQ}

Agency theory predicts that smaller boards bound to be formed for control functions such as corporate administration easier to be well-maintained (Jensen, 1993). In contrast, larger board size would lead to counseling purpose, which is related to resource independency theory (Hilman \& Dalziel, 2003). The importance of having accountable and committed board of directors has been described in the Malaysian Code of Corporate Governance (2017) which states that a corporate board is given the responsibility to ensure the navigated company is riding on the right track in achieving its long-term success along with delivering sustainable value to its shareholders and key stakeholders. According to Botti et al. (2014), the board also delivers a role in giving advice to its top executives on improving the quality of firms' IFR. Kumar \& Singh (2013) argue that it is important to have the ideal number of board of directors with immense skills and experiences in order to deliver an ideal decision for the company. Moreover, Basuony \& Mohamed (2014) in their study proves that board size influences the quality of IFR disclosures. Meanwhile, Sandhu \& 
Singh (2019) concur that larger board size is positively related to corporate internet reporting (CIR) disclosure quality. In contrast, Jensen (1993) argues that having larger board size tend to draw conflict among the directors, thereby, delaying the process of deliberating important decision for the company. The findings are also consistent with the works Alebrahem (2018), connoting that board size insignificantly related to quality of CIR disclosures. Nonetheless, Mokhtar (2017) indicates that the relationship between board characteristics such as board size, board independence along with duality role, and IFR disclosures are still considered scant especially in the emerging markets. This warrant for further research on the association between board size and IFR quality. Therefore, the above discussions have led to the hypothesis below:

$H_{1}$. There is a positive relationship between board size and IFR quality.

\subsection{Board Independence}

According to Bin-Ghanem \& Ariff (2016), large number of independent directors appointed in a corporate board can lead to effectiveness of monitoring process with respect to governance of companies. The interests of shareholders and key stakeholders are likely to be protected with greater independent directors sitting on a corporate board (Jensen \& Meckling, 1976). Furthermore, the study by Kelton \& Yang (2008) shows that the relationship between board independence and IFR disclosures and transparency are significant. They suggested that greater board independence would encourage for greater monitoring on the financial reports, which in turn, improves the quality of IFR disclosures and transparency. Nevertheless, several researchers are not in favor of the findings above. For example, the study by Ho \& Wong (2001) found that board independence is negatively related to IFR voluntary disclosures. Similarly, Basuony, Mohamed \& Samaha (2018) concur that board independence has a negative relationship with financial reports published via social media (internet). This is consistent with Alebrahem (2018) who found that board independence is negatively correlated with the quality of IFR disclosures. Agency theory envisages that interest of stakeholders particularly investors is likely to be more protected with greater number of independent directors (Jensen \& Meckling, 1976). Therefore, the second hypothesis is derived as the following:

$H_{2}$. There is a positive relationship between independent directors and IFR quality.

\subsection{Board Gender Diversity}

This research adopts the agency theory derived from the study conducted by Srinidhi et al. (2011) which explains the presence of female directors, who are more risk-adverse in nature, are likely to protect shareholders' interest better thereby reduces the agency problem between management and shareholders. The initiation of Malaysian Code of Corporate Governance (2017) has urged listed companies to appoint at least 30 percent of female directors sitting in their boards to coincide with the country's vision to raise values of transparency and accountabilities (Malaysian Code of Corporate Governance, 2017). Studies in the literature have shown that there are many advantages on having female directors on companies' board. For example, having more female on board can enhance the effectiveness on governance practices, which boosts performance of companies (Lückerath-Rovers, 2013). It is also noted that greater number of female directors found to be significantly linked to accuracy of accounting information (Clatworthy \& Peel, 2013). The findings appear to be consistent with a study by Wahid (2018) who postulates that fewer financial reporting errors and fraud are reported on companies that have greater gender-diverse board. However, the findings of previous studies appear to be inconsistent with several other studies. For instance, Cheng et al. (2000) and Westphal \& Bednar (2005) conclude that heterogeneous board can lead to complexity in terms of communication and decision-making process. Additionally, according to Krishnan and Parsons (2008), more female directors on board do not necessarily reduce earnings management. This is also supported by Peni \& Vähämaa (2010) who found no correlation between women on board and earnings management. Based on the arguments above, there is a propensity that board gender diversity further enhances quality of financial reporting (Lückerath-Rovers, 2013; Clatworthy \& Peel, 2013; Wahid, 2018). Similar results also found in the context of online financial 
reporting literature (Basuony, 2018; Pina \& Torres, 2019). Based on the arguments above, it is hypothesised that:

$H_{3}$. There is a positive relationship between female directors and IFR quality.

\subsection{Effectiveness of Internal Audit Function as the Moderating Role}

Agency theory propounds that internal audit function (IAF) plays pivotal role in decreasing agency problems between managers and shareholders as well as between executive directors and independent directors (Goodwin \& Ken, 2006; Ismael \& Roberts, 2018). Nevertheless, according to Johl et al. (2013) substitution effect may exist between board quality and internal audit quality. This means that they can be substituted for one another to determine the level of financial reporting quality. Meanwhile, Abbott et al. (2016) explain that internal auditors work scope has been gradually shifting from reporting-based to consulting activities, which warrant for higher job skills. While the roles of internal auditors are expanding, there are also emerging issues that are affecting their roles such as lack of competencies and training among internal auditors Coetzee, P., Erasmus, L. J. and Plant, 2015). The notion is consistent with the study by Kim et al. (2009), revealing that internal auditors are lack of expertise to address the use of advanced technology such as data analytics to verify specific criteria of financial reporting. Nevertheless, issues pertaining to outsourcing options has been heavily debated over the years, specifically in ascertaining whether having the function through in-house or outsourcing provides better option for a company (Ganesan et al., 2017; Raiborn et al., 2017). Previous studies have shown that the issue has yielded mixed results (Mubako, 2018). For instance, James (2003) found that outsourcing internal audit function to independent provider can enhance the value of independent as compared to in-house. Meanwhile, Prawitt et al. (2012) reveal that outsourcing IAF to external auditors are likely to reduce the risk of accounting error and fraud; subsequently enhance the quality of financial reporting. In contrast, Dickins \& O'Reily (2009) found that EIAF can be affected under outsourcing arrangement as reporting to audit committee (AC) declines with greater extent. Whereas, a study by Ege (2014) found no relationship exists between outsourcing of internal audit function and management misconduct.

EIAF has been regarded as the suitable moderator in this research following a study by Ganesan et al. (2017) that employed similar approach in other context of research framework involving corporate governance and disclosure of voluntary non-financial reporting. The study reveals that not only EIAF moderates the association between corporate governance and disclosure of non-financial information but also proves that EIAF is conceptually consistent with agency theory. Ganesan et al. (2018) also suggest for application of EFIA as a potential moderator in related context of studies but acknowledge that the mechanism requires an additional improvement in terms of providing more breakdown on outsourcing arrangement (i.e. fully or partially outsourced). Nevertheless, several researchers (Johl et al., 2013; Abbott, 2016) consider that studies on association between internal audit function and financial reporting process are still scant. This implies other contexts of financial reporting as well including IFR. The discussions above have led to the following hypothesis:

$H_{4}$. The EIAF moderates the relationship between board characteristics and IFR quality

\section{Methodology of research}

This research adopts quantitative method, requiring the extraction of secondary data from the Bursa Malaysia and corporate website. These data among others include annual reports including other nonfinancial information such as statement of corporate governance, sustainability reporting for the period of 2018. The period was chosen in correspond with the purpose of the research that is to examine the current practices code of corporate governance, also considering that most companies have uploaded their most recent reports on their websites. The process of analyzing the data requires the application of Partial Least Square (PLS) Structural Equation Modelling (SEM) technique, using statistical software of WarpPLS version 7.0. to test their internal consistency, indicator reliability, convergent validity, and discriminant validity of the measurement model (Kock, 2016). WarpPLS version 7.0 was preferred by virtue of its ability to determine sample size by using the inverse square root and gamma exponential methods (Kock, 2017). Using the desired power of .80 , significance level of 0.001 and the smallest absolute path coefficient applicable for the confirmatory dataset of .197 , the number of valid cases collected exceeded the 
recommended minimum sample size of 146. WarpPLS is also applied to deal with variables that have dichotomous characteristics including both reflection and formative measurement model (Kock, 2014), which is considered suitable in the context of this research.

\subsection{Profile of Company}

The sample of the study comprised of 11 relevant industries in Malaysia excluding financial institutions which attributed by different regulations and standards. All samples are collated from the Main Board of Bursa Malaysia through non-probability purposive sampling, given that this study has set certain criteria in selecting the sample (i.e. companies are listed in the Main Board of Bursa Malaysia, the companies have published their financial report for the year 2018 on corporate website etc.). It is also anticipated that these Main Board of listed companies should have all the necessary resources to maintain IFR as a platform for dissemination of corporate information. It was espoused to ensure the collected data were indeed from valid sources.

\subsection{Assessment of IFRQ}

A 5-point Likert scale anchored from "very poor" (1) to "excellence" (5) was used as the measurement scale for the independent and dependent variables. Specifically, the researchers assigned the scores by assessing the specific attributes provided in annual reports and corporate websites, then matched them against criteria of qualitative characteristics provided in the literature (Pirchegger \& Wagenhofer, 1999; Beest et al., 2009; Al-Dmour et al., 2017) and "The Conceptual Framework for Financial Reporting" (Malaysian Accounting Standards Board, 2018). The following step requires the researchers to compute the mean scores on per item basis of the qualitative attribute, which is based on Braam \& Van Beest (2013). The research instrument had been duly examined for pre-test (e.g. via expert view) and pilot test to ensure for its validity and applicability to be used in Malaysia.

\subsection{Analysis Model}

The hypotheses of this study are examined using Partial Least Squares-Structural Equation Modelling (PLS-SEM) using WarpPLS version 7.0. The research model is based on the following equation:

$$
\text { IFRQ }=\alpha+\beta 1 B O D S I Z E+\beta 2 I N D I R+\beta 3 F D I R+e
$$

Where IFRQ = Internet Financial Reporting Quality, BODSIZE = Board Size, INDIR = Degree of Independent Directors, and FDIR = Board Gender Diversity.

\subsection{Research Variables and Research Indicator}

Three latent variables were measured in this research that include Board of Directors characteristics (board size, degree of independent directors, and gender diversity (female directors on board) as independent/exogenous variable, EIAF implementation as moderation variable, and Internet Financial Reporting Quality as dependent/endogenous variable. All these variables are latent/unobserved (unmeasured) variables, and these are proxied by using predetermined indicators. Moreover, incomplete data may become a problem because the data obtained may not fulfil the minimum requirement of sampling. 
Table 2. Factor Loading Value of the Indicators that Explain Research Variables

\begin{tabular}{|c|c|c|c|c|}
\hline No. & Latent Variable & Coded & Indicator of Variable & Main Reference \\
\hline 1. & Board size (exogenous latent) & BODSIZE & $\begin{array}{l}\text { No. of director on board } \\
\text { "1" if 1-5 Dir } \\
\text { "2" if 6-10 Dir } \\
\text { "3" if >10 Dir }\end{array}$ & $\begin{array}{c}\text { Torchia and Calabro } \\
\text { (2016) }\end{array}$ \\
\hline 2. & $\begin{array}{l}\text { Degree of independent director } \\
\text { (exogenous latent) }\end{array}$ & INDIR & $\begin{array}{l}\text { Proportion of independent } \\
\text { director to that of total } \\
\text { board } \\
\text { " } 1 \text { " if INDIR > } 50 \% \text { on board, } \\
\text { " } 0 \text { " if otherwise }\end{array}$ & $\begin{array}{l}\text { Terjesen, Couto and } \\
\text { Francisco (2016) }\end{array}$ \\
\hline 3. & $\begin{array}{l}\text { Board gender diversity -female } \\
\text { (exogenous latent) }\end{array}$ & FDIR & $\begin{array}{l}\text { Proportion of female } \\
\text { directors to that of total } \\
\text { board size } \\
\text { "1" if }>30 \% \\
\text { "0" if }<29 \%\end{array}$ & Wahid (2018) \\
\hline 4. & $\begin{array}{l}\text { Effectiveness of internal audit } \\
\text { function (exogenous latent) }\end{array}$ & EIAF & $\begin{array}{l}\text { " } 1 \text { " if IAF in-house, } \\
\text { " } 2 \text { " if outsourced } \\
\text { " } 3 \text { " if partially outsourced }\end{array}$ & Ganesan et al. (2017) \\
\hline 5. & $\begin{array}{l}\text { Internet financial reporting } \\
\text { quality (endogenous latent) }\end{array}$ & IFRQ & $\begin{array}{l}\text { - Relevance } \\
\text { - Faithful representation } \\
\text { - Verifiability } \\
\text { - Understandability } \\
\text { - Comparability } \\
\text { - Timeliness }\end{array}$ & $\begin{array}{c}\text { Beest et al. (2009), } \\
\text { Pirchegger and } \\
\text { Wagenhofer (1999) }\end{array}$ \\
\hline
\end{tabular}

\subsection{Results and Discussions}

The assessment of research model was conducted in two stages. First, the assessment of measurement model is was conducted then followed by assessment of structural model. However, the structural model assessment would only be conducted if the research model passed the first assessment which was the assessment of measurement model. In addition, two algorithm methods were applied in this study. Outer model was examined with PLS at Regression Mode, whereas inner model was examined with warp2 (non-linear). Both methods were selected because they produced p-value with the best significance level (Sholihin \& Ratmono, 2013). Furthermore, method of resampling was stable method, which represented the default method by applying PLS-SEM with the application of WarpPLS version 7.0.

\subsection{Evaluation of Reflection Measurement Model}

Measurement model evaluation was tested to assess the reliability and validity of indicators that help to form latent variables. Table 3 reveals the findings of composite reliability (CR) constructs and convergent validity assessment. The results confirm that the constructs (or variables under investigation) have high internal consistency (Roldán \& Sánchez-Franco, 2012; Hair et al., 2017; Kock, 2017) and enough average variance extracted (AVE) to validate the convergent validity (Hair et al., 2017; Kock, 2017). As shown by the Table 3 and 6, all indicators that explain variables of IFRQ, BODSIZE, INDIR, and FDIR are valid with 1.0 factor loading values. Reason being is that this research involved using single-item measure to assess reliability and validity of the measurement model which is characterized by the nature and objective of the study. This is supported by Fuchs \& Diamantopoulos (2009) and Diamantopoulos et al. (2012), suggesting that using single-item measure should be considered in the condition when the construct variable having alpha value higher than 0.9 which resulted from higher homogeneous in an internal consistency. Furthermore, the study of Nunnally (1967) indicates that the internal consistency of measurement model is considered valid upon which the alpha values are between the range of 0.9 and 1.0. Therefore, all indicators in this study are those that have achieved indicator reliability. The rate of SquareRoot AVE is compared with the rate of correlations across the variables/constructs. Because each construct 
was higher than its highest correlation with other indicators in the same column and row, discriminant validity does exist.

Table 3. Factor Loading, Composite Reliability and Average Variance Extract

\begin{tabular}{|c|l|c|l|c|c|}
\hline No. & \multicolumn{1}{|c|}{ Latent Variable } & Coded & \multicolumn{1}{|c|}{ Indicator of Variable } & Composite Reliability & AVE \\
\hline 1. & $\begin{array}{l}\text { Board size (exogenous } \\
\text { latent) }\end{array}$ & BODSIZE & No. of director on board & 1 & 1 \\
\hline 2. & $\begin{array}{l}\text { Degree of independent } \\
\text { director INDIR } \\
\text { latent) }\end{array}$ & $\begin{array}{l}\text { Proportion of independent director } \\
\text { to that of total board }\end{array}$ & 1 & 1 \\
\hline 3. & $\begin{array}{l}\text { Board gender diversity - } \\
\text { female (exogenous latent) }\end{array}$ & FDIR & $\begin{array}{l}\text { Proportion of female directors to } \\
\text { that of total board size }\end{array}$ & 1 & 1 \\
\hline
\end{tabular}

Table 4. Square-Root AVE and Correlations across the Constructs

\begin{tabular}{|c|c|c|c|c|}
\hline \multirow{2}{*}{ Variable/Construct } & \multirow{2}{*}{ Square-Root AVE } & \multicolumn{3}{|c|}{ Correlations } \\
\cline { 3 - 5 } & & BODSIZE & INDIR & FDIR \\
\hline BODSIZE & 1.000 & 1.000 & 0.238 & 0.031 \\
\hline INDIR & 1.000 & 0.238 & 1.000 & 0.026 \\
\hline FDIR & 1.000 & 0.031 & 0.026 & 1.000 \\
\hline
\end{tabular}

\subsection{Evaluation of Formative Measurement Model}

Formative assessment to test convergent validity should have significant indicator outer weights with $p<0.05$ (Garson, 2016; Kock, 2017). As shown in Table 5, the indicator weights determine by the t-statistic and p-value specifies the significance that the indicator has for the associated latent variable (Garson, 2016; Kock, 2017). Only indicators with high indicator loadings $>0.50$ should be retained if the indicator weights are not significant (Garson, 2016; Hair et al., 2017; Kock, 2017). Assessing multicollinearity for formative latent variable theory is parallel with reflective latent variable theory (Kock, 2017). Full collinearity VIF $<3.3$ is ideal, and $\mathrm{VIF}<5.0$ is less conservative threshold, while a more relaxed $\mathrm{VIF}<10.0$ are acceptable (Diamantopoulos \& Siguaw, 2006; Hair et al., 2017; Kock, 2015, 2017; Kock \& Lynn, 2012). The indicators had a VIF<3.3. Therefore, the measurement model had no evidence of common method bias or multicollinearity (Hair et al., 2017; Kock 2015, 2017). See Table 5 for the summary of the VIF for the formative constructs.

The results show that not all formative indicators are significant except for relevance, understandability, and comparability. Reason being is that the number of measured items under individual qualitative characteristic is not equal. However, prior research or theory including "The Conceptual Framework for Financial Reporting" issued by International Accounting Standards Boards provide evidence for the relevance of these indicators for capturing the operationalize definition of the internet financial reporting quality (Beest et al., 2009; Al-Dmour et al., 2017; International Accounting Standards Board, 2018). Braam \& Van Beest (2013) explain that qualitative characteristics are conceptually based in nature which makes them difficult to be interpreted and measured separately. Furthermore, the measured items contribute to more than one attributes. Therefore, these indicators are retained in the formative constructs even though their outer weights are not significant.

Table 5. Convergent Validity, Composite Reliability, Common Method Bias, and Multicollinearity

\begin{tabular}{|c|c|c|c|c|c|c|c|}
\hline Latent Variable & Coded & Indicator of variable & $\begin{array}{c}\text { Convergent } \\
\text { Validity }\end{array}$ & Weight & VIF & $\begin{array}{l}\text { t-value } \\
\text { weights }\end{array}$ & Sig \\
\hline \multirow{6}{*}{$\begin{array}{lr}\text { Internet } & \text { financial } \\
\text { reporting } & \text { quality } \\
\text { (Endogenous Latent) }\end{array}$} & \multirow[t]{6}{*}{ IFRQ } & Relevance & \multirow[t]{6}{*}{0.725} & 0.479 & 1.835 & 5.244 & $0.00 * *$ \\
\hline & & Faithful representation & & 0.100 & 1.762 & 1.348 & 0.178 \\
\hline & & Verifiability & & 0.095 & 1.526 & 1.327 & 0.185 \\
\hline & & Understandability & & 0.343 & 2.145 & 6.829 & $0.00 * *$ \\
\hline & & Comparability & & 0.213 & 2.055 & 4.105 & $0.00 * *$ \\
\hline & & Timeliness & & 0.026 & 1.418 & 0.268 & 0.789 \\
\hline
\end{tabular}




\subsection{Evaluation of Structural Model}

Evaluation of structural model (inner model) is intended to examine the relationship across latent variables by assessing how much variance should be explained in order to specify the significance of P-value by conducting hypothesis test (Latan \& Ghozali, 2016). Goodness-of-fit of the study must be assessed prior for evaluating the relationship across variables. The results of this evaluation are depicted in Table 6.

Table 6. Goodness-of-Fit of Structural Model

\begin{tabular}{|l|c|c|}
\hline Criteria Parameter Rule of Thumb & Acceptable if $\mathrm{P}<0.05$ \\
\hline Average path coefficient (APC) & $0.283, \mathrm{P}<0.001$ & Acceptable if $\mathrm{P}<0.05$ \\
\hline Average R-Squared (ARS) & $0.271, \mathrm{P}, 0.001$ & Acceptable if $\mathrm{P}<0.05$ \\
\hline Average Adjusted R-Squared (AARS) & $0.246, \mathrm{P}<0.001$ & Acceptable if $<=5$, Ideally $<=3.3$ \\
\hline Average full collinearity VIF (AFVIF) & 1.273 & Small $>=0.1$, medium $>=0.25$, large $>=0.36$ \\
\hline Tenenhause (GoF) & 0.498 & Acceptable if $>=$, ideally $=1$ \\
\hline Sympson's Paradox Ratio (SPR) & 0.833 & Acceptable if $>=0.9$, ideally $=1$ \\
\hline R-square Contribution Ratio (RSCR) & 0.982 & Acceptable if $>=0.7$ \\
\hline Statistical suppression ratio (SSR) & 0.833 & Acceptable if $>=0.7$ \\
\hline $\begin{array}{l}\text { Non-linear bivariate causality direction ratio } \\
\text { (NLBCDR) }\end{array}$ & 0.917 & \\
\hline
\end{tabular}

Based on the results shown in Table 6, the research model has good fit because P-values for APC, ARS, and AARS are $<0.05$, precisely APC $=0.174$, ARS $=0.274$, and AARS $=0.246$. The rates of both AVIF and AFVIF are $<3.3$, thus, there is no multicollinearity problem across indicators and across exogenous variables. Goodness-of- fit (GoF) has a rate of $0.498>0.36$, which signifies that research model has a very good fit. The parameters of SPR, RSCR, and SSR are $>0.8$ and it is considered acceptable if the parameters > 0.7 , and NLBCDR has a parameter value of 0.917 , which based on these results, it is known that there is no causality problem in research model (Latan \& Ghozali, 2016).

Table 7.The Estimated Relationship across Variables

\begin{tabular}{|c|l|c|c|c|c|}
\hline & \multicolumn{1}{|c|}{ Direct Effects } & Beta & S. E & p-value & Decision \\
\hline H1 & BODSIZE->IFRQ & 0.153 & 0.077 & 0.024 & Supported \\
\hline H2 & INDIR->IFRQ & 0.156 & 0.076 & 0.021 & Supported \\
\hline H3 & FDIR->IFRQ & 0.334 & 0.074 & $<0.001$ & Supported \\
\hline & Moderating Effects & & & & \\
\hline H4 & EIAF*BODSIZE->IFRQ & 0.041 & 0.078 & 0.299 & Not Supported \\
\hline H5 & EIAF*INDIR->IFRQ & 0.344 & 0.073 & $<0.001$ & Supported \\
\hline H6 & EIAF*FDIR->IFRQ & 0.015 & 0.079 & 0.422 & Not Supported \\
\hline
\end{tabular}

The structural model assessment examines the proposed relationship between the variables in the research framework. Table 7 demonstrates the assessment of the path coefficient, which is represented by Beta values for each path relationship. The results show all hypotheses were supported. The results for direct effects indicate that BODSIZE, INDIR, and FDIR have positive influences on IFRQ. As depicted in Figure 2 , all three proposed relationships are significant. Specifically, the study found support for $\mathrm{H}_{1}$ (BODSIZE $\rightarrow$ IFRQ, $\beta=0.153, p=0.024), \mathrm{H}_{2}$ (INDIR $\rightarrow$ IFRQ, $\left.\beta=0.156, p=0.021\right)$ and $\mathrm{H}_{3}$ (FDIR $\rightarrow$ IFRQ, $\beta=0.334, p<$ 0.001 ). Results show that board size is significantly related to IFRQ, suggesting that greater number of directors on board would push for more disclosure as this would give positive impression to the shareholders and key stakeholders (Yassin, 2017). Moreover, this may lead to a more efficient monitoring, thereby, reducing the opportunistic behavior of the managers who tend to manipulate financial reports for their personal interest (Basuony \& Mohamed, 2014; Yassin, 2017). Board size can be further explained in theoretical manner, by which under agency theory, smaller board size is expected to be formed to ensure control function operated effectively (Jensen, 1993). Larger board size is likely to be attributed by resource dependency theory, formed to perform counselling function (Hilman \& Daziel, 2003). Meanwhile, the 
independent directors appear to positively influence IFR quality which is also in line with agency theory and prior literature, indicating that higher numbers of independent directors on board further enhance the monitoring activities on preparation of financial reporting (Kelton \& Yang, 2008; Bin-Ghanem \& Ariff, 2016). The results also echoed by Kent and Stewart (2008) who connote that independent directors help to ensure the underlying mechanism, methods and accounting principles used are well justified in order to compose better objective and transparency of financial reporting. Meanwhile, the positive relationship between board gender diversity (female directors on board) indicates that higher number of females on board can provide effectiveness on governance practices and improvement on the quality of financial reporting as proven in prior literature (Lückerath-Rovers, 2013; Clatworthy \& Peel, 2013; Wahid, 2018). These accords with the agency theory, predicting that a board effectiveness and performance can be further enhanced with greater board gender diversity because female directors are more risk-adverse and meticulous in deliberating decision compared to male counterpart (Srinidhi et al., 2011; Terjesen et al., 2016).

In this study, EAIF is hypothesized $\left(\mathrm{H}_{4}-\mathrm{H}_{6}\right)$ as the moderating variable. Based on the analysis of the sample companies, the study found that about 57.5 percent listed companies outsourced their IAF to independent providers. This means that majority of listed companies in this study have opted to outsource their IAF. The findings appear to support only for $\mathrm{H}_{5}$ (independent directors). The results consistent with empirical evidence provided by Goodwin-Stewart \& Kent (2006), connoting that IAF can play a role as complementary mechanism in reducing asymmetry problems between executive and independent directors. Nevertheless, the findings of the study notably with respect to the moderating effect of EIAF on board size and female directors on board did not seem to be consistent with the anticipated research hypotheses. The findings as to why EIAF did not moderate board size are consistent Van Peursam (2005) who argue that the dual role of internal auditors; assurance provider simultaneously providing consulting services to the same client or management can cause negative effect on their independence and objectivity. Accordingly, this situation also inhibits the internal auditors to not be willingly report to AC on any issues which could jeopardize their privilege and job status (Chadwick, 2000). This notion is also echoed by Dickins \& O'Reilly (2009), noting that in-house internal auditors reporting to AC decreases as the level of outsourcing in the company becomes substantial as they become fear that they may be replaced by outsourced provider. Consequently, these to certain extent, engenders detrimental effect on the quality of financial reports. Regarding $\mathrm{H}_{6}$, board gender diversity, the findings can be related to the empirical evidence provided by Hashim et al. (2019) who conducted an examination on relationship between board diversity and earnings quality, moderated by EIAF across listed companies in Malaysia. The study concludes that the interaction of EIAF on the association between the two variables appear to be insignificant. One factor that offers explanation to the findings is the existence of substitute effect between board quality (including gender diversity) and internal audit quality as explicated by Johl et al. (2013). The findings suggest that the quality of the boards exert more influence on determining the level of financial reporting quality compared to internal audit.

Table 8. Model Quality Assessment

\begin{tabular}{|l|c|c|c|c|}
\hline \multicolumn{1}{|c|}{ Direct Effects } & $\mathbf{f}^{\mathbf{2}}$ & $\mathbf{R}^{\mathbf{2}}$ & $\mathbf{V I F}$ & $\mathbf{Q}^{\mathbf{2}}$ \\
\cline { 1 - 2 } H1: BODSIZE->IFRQ & 0.034 & 0.274 & 1.133 & \\
\cline { 1 - 2 } H2: INDIR-> IFRQ & 0.005 & & 1.065 & \\
\cline { 1 - 2 } H3: FDIR -> IFRQ & 0.123 & & 1.231 & \\
\hline
\end{tabular}

Table 8 displays the assessment quality of the model. The researchers assessed the effect size $\left(f^{2}\right)$, the coefficient of determination $\left(R^{2}\right)$, the VIF, and the predictive relevance $\left(Q^{2}\right)$ of exogenous variables on the endogenous variable (IFRQ) in this study. FDIR was shown to carry moderate effect size $\mathrm{f}^{2}$ on IFRQ. However, BODSIZE and INDIR hypotheses were found to pose small effects size $\mathrm{f}^{2}$ on IFRQ (Hair et al., 2017; Kock, 2017). The coefficient of determination represented by $R^{2}$ which explains whether BODSIZE, INDIR, and FDIR could explain the IFRQ indicates substantial effect (Chin, 1998; Garson, 2016; Hair et al., 2017; Kock, 2017). Besides, multicollinearity between indicators was assessed. All indicators for variables satisfy the VIF values and they are consistently below the threshold value of 5.0 (Hair et al., 2014) and 3.3 (Diamantopoulos \& Siguaw, 2006). Therefore, it can be concluded that collinearity issues do not reach 
critical levels in all variables and are not an issue for the estimation of the PLS path model (Kock \& Lynn, 2012; Kock, 2017). The $R^{2}$ value for attitude is 0.274 suggesting that the antecedents can explain certain number of variances for the endogenous variable. The results also reveal that FDIR have a medium effect size on attitude $\left(f^{2}=0.123\right)$. This implies that FDIR moderately influencing IFRQ. Meanwhile, BODSIZE and INDIR exert small effect size ( $f^{2}=0.034$ and $f^{2}=0.005$ respectively) on IFRQ. The predictive relevance values of all exogenous (independent) variables towards endogenous (dependent) variable were larger than 0 , indicating that the independent variables (BODSIZE, INDIR, and FDIR) could predict the IFRQ, as presented by $Q^{2}$ (Geisser, 1974; Kock, 2017).

\section{Conclusions}

The study concludes that board characteristics significantly improve IFR quality. Although EIAF only moderates independent directors, this research acknowledges the pivotal role of IAF in improving IFR quality by having a robust mechanism that can protect auditor's independence and objectivity. Further, given that majority of the companies in this study engaged with outsourced provider, effective coordination between management and outsourced provider is paramount in enhancing IFR quality. The results also verify that agency problem between managers and owners also correlated with the existence of $A C$ and IAF, indicating that the agency gap can be narrowed if both functions of $A C$ and IA are effective. The paper highlights adoption of a new measurement instrument which is derived from previous literature and based on the 'Conceptual Framework for Financial Reporting' issued by MASB (2018) to assess qualitative characteristics of IFR. Research analysis proves that the measured items are valid and reliable in assessing the qualitative nature of IFR. Thus, it can be used as a yardstick to determine qualitative attributes of IFR disclosed on corporate websites across Malaysian companies. Furthermore, the empirical study enriches the existing literature on board characteristics including providing guidelines to enhance the current practices of corporate governance. This research concedes several limitations those points to future research. Given the online financial reporting is vulnerable to security risk (e.g. business cyber attacked, unauthorised access, manipulation of hyperlink), the research could be improved by incorporating mechanisms or measured items that could evaluate quality of internal control system in addressing security risk on corporate websites. Additionally, it is imperative for the boards to seek robust strategies to promote organizational commitment to leverage the enormous benefits of technology in order to remove information risk. These would further enhance reliability of online corporate reporting. Nevertheless, regulatory bodies and key stakeholders need to synergize the available resources in setting up robust regulatory environment and a specific standard to better governing IFR practices. Our research indicates that board characteristics hold the key to improve IFRQ that spur the market efficiency in the age of industrial revolution 4.0 .

\section{References}

1. Abbott, L. J., Daugherty, B., Parker, S., \& Peters, G. (2015). Internal Audit Quality: The Joint Importance of Independence and Competence. Academy of Management Proceedings, 2015(1), 18444.

2. Alali, F., Romero, S. (2012). The use of the Internet for corporate reporting in the Mercosur (Southern common market): The Argentina case. Advances in Accounting, 28(1), 157-167.

3. Ahmed, A-D., Abbod, M. F., Hani, Al-Dmour H. (2017). Qualitative Characteristics of Financial Reporting and Non-Financial Business Performance. International Journal of Corporate Finance and Accounting, 4(2), 1-22.

4. Alebrahem, N. (2018). Corporate internet reporting, firm characteristics, corporate governance and firm financial performance of Saudi listed companies (Doctoral dissertation, University of Plymouth).

5. Ali Khan, M. N. A., \& Ismail, N. A. (2012). An empirical study on the indexes of internet financial reporting: The case of Malaysia, African Journal of Business Management, 6(5), 2086-2100.

6. Ali Khan, M. N. A., \& Ismail, N. A. (2011). The Level of Internet Financial Reporting of Malaysian Companies. Asian Journal of Accounting and Governance, 2(1), 27-39.

7. Almilia, L. S. (2015). Comparing internet financial reporting practices: Indonesia, Malaysia, Singapore, Japan and Australia. International Journal of Business Information Systems, 20(4), 477-495. 
8. Aly, D., Simon, J., \& Hussainey, K. (2010). Determinants of corporate internet reporting: evidence from Egypt. Managerial Auditing Journal, 25(2), 182-202.

9. Amin, H. M. G., \& Mohamed, E. K. A. (2016). Auditors' perceptions of the impact of continuous auditing on the quality of Internet reported financial information in Egypt. Managerial Auditing Journal, 31(1), 111-132.

10. Ariff, A. M., Bin-Ghanem, H. O., \& Hashim, H. A. (2018). Corporate Ownership, Internet Penetration and Internet Financial Reporting: Evidence from the Gulf Cooperation Council Countries. Asian Journal of Business and Accounting, 11(1), 185-227.

11. Basuony, M. A. K., Mohamed, E. K. A., \& Samaha, K. (2018). Board structure and corporate disclosure via social media: an empirical study in the UK. Online Information Review, 42(5), 595-614.

12. Basuony, M. A. K., \& Mohamed, E. K. A. (2014). Board composition, ownership concentration, and voluntary internet disclosure by MSM-listed companies. Corporate Board Role Duties and Composition, 10(1), 60-70.

13. Beest, F. Van., Braam, G., And Boelens, S. (2009). Quality of financial reporting: measuring qualitative characteristics, NiCE Working Paper 09-108,1-41.

14. Bin-Ghanem, H., \& Ariff, A. M. (2016). The effect of board of directors and audit committee effectiveness on internet financial reporting, Journal of Accounting in Emerging Economies. 6(4), 429-448.

15. Botti, L., Boubaker, S., Hamrouni, A., \& Solonandrasana, B. (2014). Corporate governance efficiency and internet financial reporting quality. Review of Accounting and Finance, 13(1), 43-64.

16. Braam, G., \& Van Beest, F. (2013). Conceptually-based financial reporting quality assessment. An empirical analysis on quality differences between UK annual reports and US $10-K$ reports. Working Paper.

17. Burritt, R., \& Christ, K. (2016). Industry 4.0 and environmental accounting: a new revolution? Asian Journal of Sustainability and Social Responsibility, 1(1), 23-38.

18. Campbell, K., \& Mínguez-Vera, A. (2007). Gender Diversity in the Boardroom and Firm Financial Performance. Journal of Business Ethics, 83(3), 435-451.

19. Cassar, C., Heath, D., \& Micallef, L. (2019). What is digital economy? Unicorn, transformation and internet of things. Mriehel, Malta. Retrieved from https://www2.deloitte.com/mt/en/profiles/ dheath.html

20. Chadwick, W. E. (2000). Keeping internal auditing in-house. Internal Auditor, 57(3), 88.

21. Cheng, A., Hooper, K., \& Davey, H. (2000). A Capital Gains Tax for New Zealand: A Comparative Study of the UK and Australian Models. Asian Review of Accounting, 8(2), 43-59.

22. Chin, W. W. (1998). The partial least squares approach to structural equation modeling. Modern methods for business research, 295(2) 295-336.

23. Clatworthy, M. A., \& Peel, M. J. (2013). The impact of voluntary audit and governance characteristics on accounting errors in private companies. Journal of Accounting and Public Policy, 32(3), 125.

24. Coetzee, P., Erasmus, L. J., \& Plant, K. (2015). Global assessment of internal audit competence: Does one size fit all? Southern African Business Review, 19(2), 1-21.

25. CPA Australia. (2020). The CPA Australia Asia-Pacific Small Business Survey 2019-20. CPA Australia's $11^{\text {th }}$ Annual Report on Small Business Issues and Sentiment Across Eleven Economies in the AisaPacific. Retrieved from https://www.cpaaustralia.com.au/-/media/corporate/allfiles/document/ professional-resources/business-management/small-business-survey/small-business-survey-2019-marketsummary-malaysia.pdf?la=en\&rev=2fc2a71a61084558b8e348538e457373

26. Cumming, D., Johan, S., \& Schweizer, D. (2017). Information systems, agency problems, and fraud. Information Systems Frontiers, 19(3), 421-424. doi:10.1007/s10796-017-9761-3

27. Davey, H., \& Homkajohn, K. (2004). Corporate internet reporting: an Asian example. Problems and Perspectives in Management, 2(2), 211-227.

28. Das, S. (2015). An Investigation of Corporate Internet Reporting in an Emerging Economy: A Case Study of Bangladesh. Ph.D Thesis. University of Sunderland; 2015.

29. Desai, N. K., Gerard, G. J., \& Tripathy, A. (2011), Internal audit sourcing arrangements and reliance by external auditors, Auditing: A Journal of Practice \& Theory, 30(1,) 149-171. 
30. Dharmadasa, P., Gamage, P., \& Herath, S. K. (2014). Corporate governance, board characteristics and firm performance: Evidence from Sri Lanka. South Asian Journal of Management, 21(1), 7-31.

31. Diamantopoulos, A., Sarstedt, M., Fuchs, C., Wilczynski, P., \& Kaiser, S. (2012). Guidelines for choosing between multi-item and single-item scales for construct measurement: a predictive validity perspective. Journal of the Academy of Marketing Science, 40(3), 434-449.

32. Diamantopoulos, A., \& Siguaw, J. A. (2006). Formative Versus Reflective Indicators in Organizational Measure Development: A Comparison and Empirical Illustration. British Journal of Management, 17(4), 263-282.

33. Dickins, D., \& O'reilly, D. (2009). The qualifications and independence of internal auditors. Internal Auditing, 24(3), 14-21.

34. Dolinsek, T., \& Lutar-Skerbinjek, A. (2018). Voluntary disclosure of financial information on the internet by large companies in Slovenia. Kybernetes, 47(3), 458-473.

35. Dyczkowska, J. (2014). Assessment of quality of internet financial disclosures using a scoring system. A case of Polish stock issuers, Accounting and Management Information Systems, 13(1), 50-81.

36. Efimova, O., \& Rozhnova, O. (2018). The Corporate Reporting Development in the Digital Economy. Digital Science, 71-80.

37. Ege, M. S. (2014). Does Internal Audit Function Quality Deter Management Misconduct? The Accounting Review, 90(2), 495-527. doi:10.2308/accr-50871

38. Ezat, A., \& El-Masry, A. (2008). The impact of corporate governance on the timeliness of corporate internet reporting by Egyptian listed companies. Managerial Finance, 34(12), 848-867.

39. FASB. (2013). Proposed Accounting Standards Update - Financial Instruments-Overall (Subtopic 825-10): Recognition and Measurement of Financial Assets and Financial Liabilities."FASB.org. Financial Accounting Standards Board.

40. Fuchs, C. \& Diamantopoulos, A. (2009). Using single-item measures for construct measurement in management research: Conceptual issues and application guidelines. Die Betriebswirtschaft, 69(2), 195210.

41. Gajewski, J.-F., \& Li, L. (2015). Can Internet-based disclosure reduce information asymmetry? Advances in Accounting, 31(1), 115-124.

42. Ganesan, Y., Hwa, Y. W., Jaaffar, A. H., \& Hashim, F. (2017). Corporate governance and sustainability reporting practices: the moderating role of internal audit function. Global Business and Management Research, 9(4s), 159-179.

43. Garson, G. D. (2016). Partial Least Squares (PLS-SEM): 2016 Edition.

44. Geisser, S. (1974). A predictive approach to the random effect model. Biometrika, 61(1), 101107.

45. Hair, J. F., Hult, G. T. M., Ringle, C. M., Sarstedt, M., \& Thiele, K. O. (2017). Mirror, mirror on the wall: a comparative evaluation of composite-based structural equation modeling methods. Journal of the Academy of Marketing Science, 45(5), 616-632.

46. Hair, Jr, J. F., Sarstedt, M., Hopkins, L., \& Kuppelwieser, G. V. (2014). Partial least squares structural equation modeling (PLS-SEM). European Business Review, 26(2), 106-121.

47. Hanafi, S. R., Kasim, M. A., Ibrahim, M. K., \& Hancock, D. R. (2009). Business Reporting on the Internet: Development of a Disclosure Quality Index, International Journal of Business and Economics, 8(1), 55-79.

48. Hashim, F., Ahmed, E. R., \& Huey, Y. M. (2019). Board Diversity and Earning Quality: Examining the Role of Internal Audit as a Moderator. Australasian Accounting, Business and Finance Journal, 13(4), 7391.

49. Hassan, O. A., \& Marston, C. (2010). Disclosure measurement in the empirical accounting literature-a review article, Accountancy Discussion Paper, Accountancy Research Group, Heriot Watt University, 1-50.

50. Hillman, A. J., \& Dalziel, T. (2003). Boards of directors and firm performance: Integrating agency and resource dependence perspectives. Academy of Management review, 28(3), 383-396. 
51. Ho, S. S., \& Wong, S. K. (2001). A study of the relationship between corporate governance structures and the extent of voluntary disclosure. Journal of International Accounting, Auditing and Taxation, 10(2), 139-156.

52. International Accounting Standards Board. (2018). The Conceptual Framework for Financial Reporting 2018. Retrieved from https://www.iasplus.com/en/standards/other/framework

53. James, K. L. (2003). The Effects of Internal Audit Structure on Perceived Financial Statement Fraud Prevention. Accounting Horizons, 17(4), 315-327.

54. Jensen, M. C. (1993). The Modern Industrial Revolution, Exit, and the Failure of Internal Control Systems. The Journal of Finance, 48(3), 831-880.

55. Jensen, M. C., \& Meckling, W. H. (1976). Theory of the firm: Managerial behavior, agency costs and ownership structure. Journal of Financial Economics, 3(4), 305-360.

56. Johl, K. S., Kaur Johl, S., Subramaniam, N. \& Cooper (2013). Internal audit function, board quality and financial reporting quality: evidence from Malaysia, Managerial Auditing Journal, 28(9), 780-814.

57. Jonas, G. J., \& Blanchet, J. (2000). Assessing quality of financial reporting. Accounting Horizons, 14(3), 353-363.

58. Kamalluarifin, W. F. S. W. (2016). The Influence of Corporate Governance and Firm Characteristics on the Timeliness of Corporate Internet Reporting by Top 95 Companies in Malaysia. Procedia Economics and Finance, 35, 156-165.

59. Keliwon, K. B., Abdul Shukor, Z., \& Hassan, M. S. (2017). Measuring Internet Financial Reporing (IFR) Disclosure Strateg. Asian Journal of Accounting and Governance, 8(Special Issue), 7-24.

60. Keliwon, K. B., Abdul Shukor, Z., \& Hassan, M. S. (2018). Internet Financial Reporting (IFR) Disclosure Position and Firm Value. Asian Journal of Accounting and Governance, 9, 111-122.

61. Kent, P., \& Stewart, J. (2008). Corporate governance and disclosure on the transition to IFRS. Journal of Accounting and Finance, 48(1), 649-671.

62. Khadaroo, I. (2005). Corporate reporting on the internet: some implications for the auditing profession. Managerial Auditing Journal, 20(6), 578-591.

63. Khan, T. (2007). Internet Financial Reporting: Disclosure about Companies on Websites. Journal of Business Systems, Governance and Ethics, 2(2), 37-46.

64. Kim, H. J., Mannino, M., \& Nieschwietz, R. J. (2009). Information technology acceptance in the internal audit profession: Impact of technology features and complexity, International Journal of Accounting Information Systems, 10(4), 214-228.

65. Kelton, A. S., \& Yang, Y. (2008). The impact of corporate governance on Internet financial reporting. Journal of Accounting and Public Policy, 27(1), 62-87.

66. Kock, N. (2017). WarpPLS user manual: Version 6.0. ScriptWarp Systems: Laredo, TX, USA.

67. Kock, N. (2016). Advantages of nonlinear over segmentation analyzes in path models, International Journal of e-Collaboration, 12(4), 1-6.

68. Kock, N., \& Lynn, G. (2012). Lateral Collinearity and Misleading Results in Variance-Based SEM: An Illustration and Recommendations. Journal of the Association for Information Systems, 13(7), 546-580.

69. Krishnan, G. V., \& Parsons, L. M. (2008). Getting to the bottom line: An exploration of gender and earnings quality, Journal of Business Ethics, 78(1-2), 65-76.

70. Kumar, N., \& Singh, J. P. (2013). Effect of board size and promoter ownership on firm value: some empirical findings from India. Corporate Governance: The International Journal of Business in Society, 13(1), 88-98.

71. Latan, H., \& Ghozali, I. (2016). Partial Least Square Concepts, Methods and Applications Using WarpPLS 5.0.

72. Leung, S., Parker, L., \& Courtis, J. (2015). Impression management through minimal narrative disclosure in annual reports. The British Accounting Review, 47(3), 275-289.

73. Lückerath-Rovers, M. (2011). Women on boards and firm performance. Journal of Management \& Governance, 17(2), 491-509.

74. Lymer A., Debreceny, R., Gray, G., \& Rahman, A. (1999). Business reporting on the internet. London: International Accounting Standard Committee. 
75. Malaysian Accounting Standards Board. (2018). The Conceptual Framework for Financial Reporting. Available athttp://www.masb.org.my/pdf.php?pdf=BV2018_revised_CONCEPTUAL\%20FRAME WORK.pdfandfile_path=pdf_file (accessed 18 April 2019)

76. Malaysian Securities Commission (2017). Malaysian Code of Corporate Governance. Available at https://www.sc.com.my/wp-content/uploads/eng/html/ cg/mccg2017.pdf (accessed 18 April 2019)

77. Mbobo, M. E., \& Ekpo, N. B. (2016). Operationalising the qualitative characteristics of financial reporting. International Journal of Finance and Accounting, 5(4), 184-192.

78. Mokhtar, E. S. (2017). Internet financial reporting determinants: a meta-analytic review. Journal of Financial Reporting and Accounting, 15(1), 116-154.

79. Mousa, G. A., Desoky, A. M., \& Sanusi, Z. M. (2012). The association between internal governance mechanisms and corporate value: Evidence from Bahrain. Asian Academy of Management Journal of Accounting and Finance, 8(1), 67-92.

80. Mubako, G. (2018). Internal Audit Outsourcing: A Literature Synthesis and Future Directions. Australian Accounting Review, 29(3), 532-545.

81. Nel, G. F. (2016). Internet investor relations, information asymmetry and the cost of capital: Evidence from JSE listed companies (Doctoral dissertation, Stellenbosch: Stellenbosch University).

82. Nunnally, J. C. (1967). Psychometric Theory, (1 st Ed.). New York: McGraw-Hill.

83. Ojah, K., \& Mokoaleli-Mokoteli, T. (2012). Internet financial reporting, infrastructures and corporate governance: An international analysis. Review of Development Finance, 2(2), 69-83.

84. Peni, E., \& Vähämaa, S. (2010). Female executives and earnings management. Managerial Finance, 36(7), 629-645.

85. Pina, V., \& Torres, L. (2019). Online transparency and corporate governance in Spanish governmental agencies. Online Information Review, 43(4), 653-675. doi:10.1108/oir-03-2018-0102

86. Pirchegger, B., \& Wagenhofer, A. (1999). Financial information on the Internet: a survey of the homepages of Austrian companies. European Accounting Review, 8(2), 383-395. doi:10.1080/096381899336113

87. Prawitt, D. F., Smith, J. L., \& Wood, D. A. (2009). Internal Audit Quality and Earnings Management. The Accounting Review, 84(4), 1255-1280.

88. Public Oversight Board. (1993). In the public interest: A special report by the public oversight board of the SEC practice section, AICPA. Stamford, CT: POB.

89. Raiborn, C., Butler, J. B., Martin, K., \& Pizzini, M. (2017). The internal audit function: A prerequisite for Good Governance. Journal of Corporate Accounting \& Finance, 28(2), 10-21.

90. Roldán, J. L., \& Sánchez-Franco, M. J. (2012). Variance-Based Structural Equation Modeling. Research Methodologies, Innovations and Philosophies in Software Systems Engineering and Information Systems, 193-221.

91. Sandhu, A., \& Singh, B. (2019). Board composition and corporate reporting on internet: Indian evidence. Journal of Financial Reporting and Accounting, 17(2), 292-319.

92. Sherman, H. D., \& Young, S. D. (2016). Where financial reporting still falls short. Harvard Business Review, 94(7), 77-84. Available https://dialnet.unirioja.es/servlet/articulo?codigo=5554603 (accessed 31 May 2020)

93. Sholihin, M., \& Ratmono, D. (2013). "Analisis SEM-PLS dengan WarpPLS 3.0 untuk Hubungan Nonlinier dalam Penelitian Sosial and Bisnis [Analysis of SEM-PLS with WarpPLS 3.0 for Nonlinear Relationships in Social and Business Research]", Yogyakarta: ANDI

94. Sia, C. J., Brahmana, R., \& Memarista, G. (2018). Corporate internet reporting and firm performance: Evidence from Malaysia. Contemporary Economics, 12(2), 153-165.

95. Srinidhi, B., Gul, F. A., \& Tsui, J. (2011). Female Directors and Earnings Quality*. Contemporary Accounting Research, 28(5), 1610-1644.

96. Terjesen, S., Couto, E.B. \& Francisco, P.M. (2016). Does the presence of independent and female directors impact firm performance? A multi-country study of board diversity. Journal of Management \& Governance, 20(3), 447-483. 
97. Torchia, M., \& Calabro, A. (2016). Board of directors and financial transparency and disclosure. Evidence from Italy. Corporate Governance: The International Journal of Business in Society, 16(3), 593608.

98. Van Peursem, K. A. (2005). Conversations with internal auditors: The power of ambiguity. Managerial Auditing Journal, 20(5), 489-512.

99. Wahid, A. S. (2018). The Effects and the Mechanisms of Board Gender Diversity: Evidence from Financial Manipulation. Journal of Business Ethics, 159(3), 705-725.

100. Wen, Y., Rwegasira, K., \& Bilderbeek, J. (2002). Corporate Governance and Capital Structure Decisions of the Chinese Listed Firms. Corporate Governance, 10(2), 75-83.

101. Westphal, J. D., \& Bednar, M. K. (2005). Pluralistic ignorance in corporate boards and firms' strategic persistence in response to low firm performance. Administrative Science Quarterly, 50(2), 262298.

102. Xiao, J. Z., Yang, H., \& Chow, C. W. (2004). The determinants and characteristics of voluntary Internet-based disclosures by listed Chinese companies. Journal of Accounting and Public Policy, 23(3), 191225.

103. Yassin, M. M. (2017). The determinants of internet financial reporting in Jordan: financial versus corporate governance. International Journal of Business Information Systems, 25(4), 526. 